\title{
Impact of Public Debt on Economic Growth in Advanced Economies
}

\author{
Amílcar Serrão \\ Management Department \\ Evora University, Evora, Portugal \\ aserrao@uevora.pt
}

\begin{abstract}
This paper examines the impact of public debt on the economic growth in advanced economies over a period of 1946 to 2009, using an econometric approach. The findings suggested an inverse relationship between public debt and economic growth in advanced economies. These relationships were found to be significant as well. Model results also show that the real GDP growth rate does not decline sharply whether the public debt-to-GDP ratio is lower than 220\%. The public debt-to-GDP ratio elasticity of the real growth rate shows that an increase of $1 \%$ in public debt/GDP category above $120 \%$ decreases the real GDP growth rate in $1.13 \%$. The negative effect of public debt is only stronger on the real GDP growth rate in advanced economies when the public debt-to-GDP ratio is above 220\%. Finally, these findings lead us to reassess the austerity agenda, and the governments should devise new strategies for public debt management in advanced economies, taking into account their economic and financial performance.
\end{abstract}

Keywords: public debt; economic growth; nonlinearity; threshold effects

\section{INTRODUCTION}

The financial and economic crisis induced by the US subprime mortgage market resulted in a great recession in many economies. Governments and central banks reacted to this recession with an expansionary fiscal and monetary policy and banking sector bailouts of the financial system which prevented the collapse of the financial system. Discretionary fiscal policies and banking sector bailouts generate a strong increase in the public debt-to-GDP ratio in many countries (Égert, 2012). A sharp increase in public debt has strong negative effects on economic growth. Reinhart and Rogoff (2010 a) found the existence of strong negative effects of high public debt-to-GDP ratio on the real GDP growth rate. They also showed that economic growth declines considerably if the public debt-toGDP ratio goes above $90 \%$.

Many papers have analyzed the decrease of economic growth and have explained the possibility of a negative nonlinear relationship between public debt and economic growth. They also confirm that the turning point beyond which economic growth goes down is around 90\%. Cecchetti et al. (2011) find a threshold of 86\% of GDP for a panel of 18 OECD countries and the period from 1980 to 2010. Padoan et al. (2012) report similar effects for a similar group of countries but a longer period (1960 to 2010). Kumar and Woo (2010) find a turning point at 90\% of GDP for a mix of advanced and emerging market economies. Checherita and Rother (2010) and Baum et al. (2012) report similar results for a set of European Union countries. Caner et al. (2010) and Elmeskov and Sutherland (2012) show that the tipping point probably lower: $77 \%$ for a set of 77 countries, and $66 \%$ for a dozen of OECD countries, respectively. Panizza and Presbitero (2012) argue that a negative correlation between debt and economic growth does not imply causality, but a lower economic growth can result in a higher public debt-to-GDP ratio. New research works started casting doubt on the one-size-fits-all feature of the $90 \%$ debt threshold. This paper looks for identifying possible thresholds beyond which the real GDP growth rate and the public debt-to-GDP ratio are negatively associated. Firstly, we compare the threshold of 90\% proposed by Reinhart and Rogoff (2010) and a threshold of 120\% proposed by Herndon et al.(2013) using an econometric model, and the elasticity concept to analyze the impact of public debt-to-GDP ratio on the real GDP growth rate in advanced countries for the period 1946 to 2009. Finally, we analyze the negative nonlinear relationship between the public debtto-GDP ratio and the real GDP growth rate using a nonparametric method. 
The paper is organized as follows. The second section presents a literature review of the effects of public debt on economic growth. The third section develops the methodology to analyze the effects of the public debt-to-GDP ratio on the real GDP growth rate. The fourth section describes the data and information. The fifth section presents empirical results and discussion. The last section summarizes and provides some policy implications.

\section{LITERATURE REVIEW}

Economies facing debt crisis have to face many challenges. Debt overhang depresses investment and economic growth in an economy. As the size of the public debt increases, the uncertainty about government's actions and policies to meet its debt servicing obligations also increase (Atique and Malik, 2012). Reinhart and Rogoff (2010 a) use descriptive statistics to show that public debt as a share of real GDP may have a negative effect on the real GDP growth rate. They present a critical public debt-to-GDP ratio, beyond which the real GDP growth rate slows down considerably. The average GDP growth rate drops from around 3\% to below 2\% as public debt exceeds the threshold of $90 \%$ of GDP in a group of selected advanced countries (Égert, 2012). They say that the fall is more dramatic if economic growth is measuredregarding the median instead of average. The real GDP growth rate is relatively stable around 3 to $4 \%$ percent until the public debt-to-GDP ratio reaches 90 percent. At that point and beyond, the average real GDP growth rate drops sharply to zero or slightly negative (Herndon et al., 2013). Herndon, Ash, and Pollin's results contradict Reinhart and Rogoff's claim. They say that there exists nonlinearity in the relationship between public debt-to-GDP ratio and the real GDP growth rate. Their results also indicate that the real GDP growth rate tails off somewhat when public debt-to-GDP ratio increases toward 120 percent, but there is not a sharp turning point. Most recently, many papers published have put in doubt the 90\% debt threshold (Égert, 2015). Minea and Parent (2012) find a debt threshold at 115\% of GDP. Panizza and Presbitero (2012) argue that a negative correlation between debt and growth does not imply causality, as lower growth can result in a higher public debt-to-GDP ratio.

\section{Methodology}

The economic theory suggests if a country utilizes the borrowed money in productive investments then this country can increase its economic growth. However, a large external debt may cause a negative effect on economic growth (Atique and Malik, 2012). If the accumulate debt amount crosses the threshold level of a country's growth, this will negatively affect the economic growth of the country because the debt plays the role of a tax on the future output.

The regression analysis shows the real growth difference associated with the higher public debt/GDP categories about the 0-30 percent public debt/GDP category. The real GDP growth rate is taken as the dependent variable, and the public debt/GDP categories are the independent variables. The study uses a regression of the real GDP growth rate by country-year on a set of variables for public debt/GDP categories by country-year. After estimating regression equations, the public debt-to-GDP ratios elasticities of the real GDP growth rates were calculated. The public debt/GDP ratio elasticity of the real GDP growth rate measures how the real GDP growth rate changes in response to a change in the public debt/GDP ratio. This regression equation is specified as follows:

$\mathrm{dRGDP}_{\mathrm{t}}=\alpha_{0}+\alpha_{1}$ Dgcati $_{\mathrm{t}}+\varepsilon_{\mathrm{t}}$

Where

$\mathrm{dRGDP}_{\mathrm{t}}=$ the real GDP growth rate by country-year; and,

Dgcati $_{\mathrm{t}}=$ public debt/GDP category by country-year.

The relationship between the real GDP growth rate and the public debt/GDP category is expected to be negatively related, and the elasticities are also expected to be much higher for the threshold of $120 \%$ than for the threshold of $90 \%$.

Before starting the analysis, the data is checked. Whether it is stationary or not before starting this study. If the variables under this study are non-stationary, then they may lead to inauthentic results, so it's important that the series of data is stationary. We applied the Augmented Dickey-Fuller (ADF) test and Ng-Perron test to check the stationarity of the variables. The unit root test presented by NgPerronis considered to be most appropriate for the small size of data in comparison to other unit root tests (Ng and Perron, 2001). 
After checking for stationarity, we test cointegration. This test tells us whether there exists along-term relationship between the variables. The prerequisite for applying this test is first to check for unit root so that it is decided whether the series are stationary or not. For testing the existence of cointegration between the variables, a method developed by Johansen and Juselius (1990) is used.

We also test for parameter instability using the CUSUM test (Brown, Durbin, and Evans, 1975). This test is based on the cumulative sum of the recursive residuals. This option plots the cumulative sum together with the 5\% critical lines. The parameter instability is found if the cumulative sum goes outside the area between the two critical lines (Kleiber and Acheim, 2008).

Some tests are used to check the validity of the model. We check whether the variance of the residuals is homoscedastic or heteroscedastic. The White Heteroscedasticity test is appliedto the regression model. By using the Breusch-Godfrey Serial Correlation LM Test, we check whether there exists autocorrelation or not (Atique and Malik, 2012).

A locally smoothed regression function is estimated with the general additive model with integrated smoothness estimation using STATA program. The smoothing parameter is selected with the default cross-validation method. Alternative methods smoothing parameters produced similar results.

\section{DATA AND INFORMATION}

The data collected include the real GDP growth rate across varying levels of the public debt-to-GDP ratio for twenty advanced countries over the period 1946-2009. The advanced countries are Australia, Austria, Belgium, Canada, Denmark, Finland, France, Germany, Greece, Ireland, Italy, Japan, Netherlands, New Zealand, Norway, Portugal, Spain, Sweden, the United Kingdom, and the United States. Firstly, the annual observations were grouped into four categories, according to the public debt-to-GDP ratio during that particular year as follows: years when the levels of public debt-to-GDP ratio were below 30 percent; years where the public debt-to-GDP ratio was 30 to 60 percent; 60 to 90 percent; and, above 90 percent. Later, the annual observations were grouped into five categories, according to the public debt-to-GDP ratio during that particular year as follows: years when the levels of public debt-to-GDP ratio were below 30 percent; years where public debt-to-GDP ratio was 30 to 60 percent; 60 to 90 percent; 90 to 120 percent; and, above 120 percent. Data of the real GDP growth rate and public debt-to-GDP ratio were collected from Reinhart and Rogoff dataset made public by Herndon et al. (2013).

\section{EMPIRICAL RESULTS AND DISCUSSION}

We test the stationarity of the real GDP growth rate $\left(\mathrm{dRDGP}_{\mathrm{t}}\right)$ variable and public debt-to-GDP ratio (Dgcati ${ }_{t}$ ) variable. The Augmented Dickey-Fuller (ADF) test and Ng-Perron test are applied to test the stationarity of the real GDP growth rate $\left(\mathrm{dRDGP}_{\mathrm{t}}\right)$ and the public debt-to-GDP ratio $\left(\mathrm{Dgcati}_{\mathrm{t}}\right)$. The results of the unit root test are presented in Table 1.

Table1. Results of the unit root tests

\begin{tabular}{|l|l|l|l|}
\hline Variables & Values & Lags & p-values \\
\hline dRGDP $_{\mathrm{t}}$ & & & \\
\hline The Dickey-Fuller test & -8.142 & 10 & 0.01 \\
\hline The Philips-Perron test & -891.3 & 7 & 0.01 \\
\hline Dgcati $i_{\mathrm{t}}$ & & & \\
\hline The Dickey-Fuller test & -5.860 & 10 & 0.01 \\
\hline The Philips-Perron test & -83.01 & 7 & 0.01 \\
\hline
\end{tabular}

Source: Author's calculation using Reinhart and Rogoff's dataset made public by Herndon et al. (2013).

The results show that the null hypothesis is rejected for a significant level of 5\%, and all the variables are found to be stationary, and they are integrated of the same order, so this concludes that there is a possibility of along-term association between the variables. To discover the long-term association between variables under study, Johansen's Cointegration test is applied. The results are shown in Table 2.

Table2. Cointegration test results

\begin{tabular}{|l|l|l|l|l|}
\hline & Statistical test value & $10 \mathrm{pct}$ & $5 \mathrm{pct}$ & $1 \mathrm{pct}$ \\
\hline $\mathrm{r} \beta 1$ & 42.36 & 7.52 & 9.42 & 12.97 \\
\hline $\mathrm{r}=0$ & 421.49 & 17.85 & 19.96 & 24.60 \\
\hline
\end{tabular}

Source: Author's calculation using Reinhart and Rogoff's dataset made public by Herndon et al. (2013). 
According to the results, the null hypothesis of no cointegration is rejected, and the cointegration test tells us that there exists a long-term relationship between the variables. The results of the CUSUM test (Brown,Durbin, and Evans, 1975) is present In Figure 1.

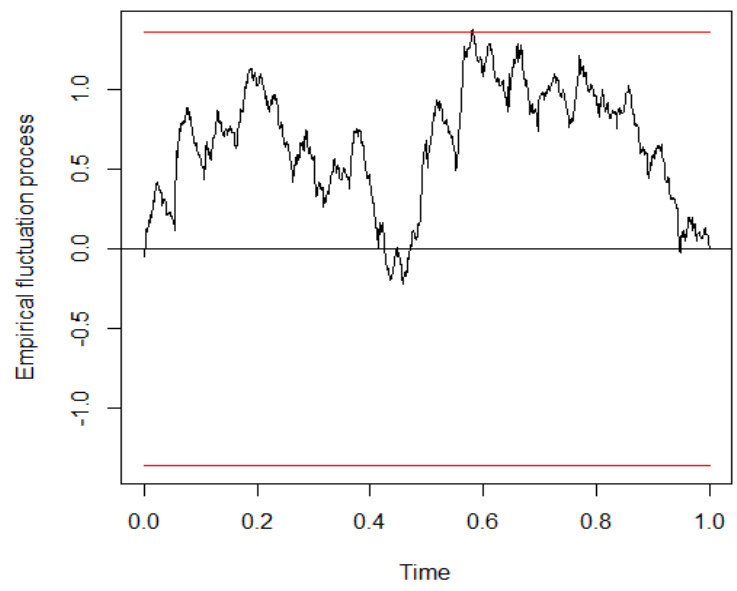

Figure1. The CUMSUM Test Results

Source: Author's calculation using Reinhart and Rogoff dataset made public by Herndon et al. (2013).

The results of the CUSUM test indicate that the parameter instability is not found because the cumulative sum does not go outside the area between the two critical lines. After the testing analysis, we present a regression analysis of the real GDP growth rate by public debt/GDP category and their elasticities (Table 3).

Table3. Model results - Regression of the real GDP growth ratein public debt/GDP categories and the public debt-to-GDP ratioselasticities of the real GDP growth rates

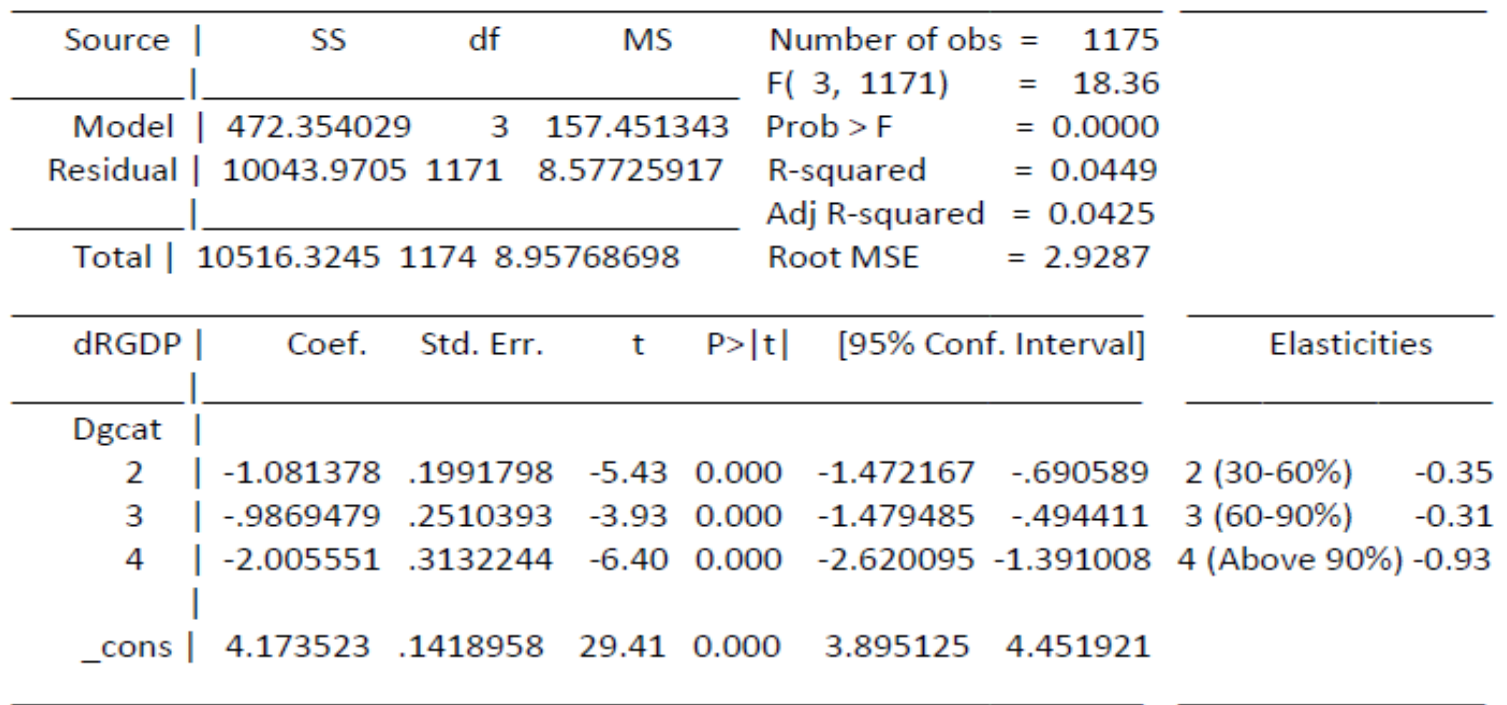

Source: Author's calculation using Reinhart and Rogoff dataset made public by Herndon et al. (2013).

The estimated equation of this model is written below:

$\mathrm{dRGDP}_{\mathrm{t}}=4.173523-1.081378$ Dgcat $_{\mathrm{t}}-0.9869479$ Dgcat $_{\mathrm{t}}-2.005551$ Dgcat $4_{\mathrm{t}}$

(0.1418958) (0.1991798) (0.2510393) (0.3132244)

The estimated values are the average GDP growth rate differences for each category with standard error in parentheses. Each independent variable shows the growth difference associated with the higher public debt/GDP categories about the 0-30 percent public debt/GDP category.

The annual observations were grouped into categories, according to the higher debt/GDP categories relative to the 0-30 percent public debt/GDP category as follows: the 30-60 percent public debt/GDP category (Dgcat2); 60 to 90 percent (Dgcat3); and, above 90 percent (Dgcat4) which is the highest category. 
From regression analysis, the results show an inverse relationship between public debt/GDP categories and the real GDP growth rate (Table 3). The real GDP growth rate in the category of public debt/GDP above 90 percent is lower by about onepercentage point than the real GDP growth ratein the 30-60 percent and 60-90 percent public debt/GDP categories. This relationship is supported by a research work (Herndon et al., 2013).

Table4. Model results - Regression of the real GDP growth rate in public debt/GDP categories and the public debt-to-GDP ratios elasticities of the real GDP growth rates

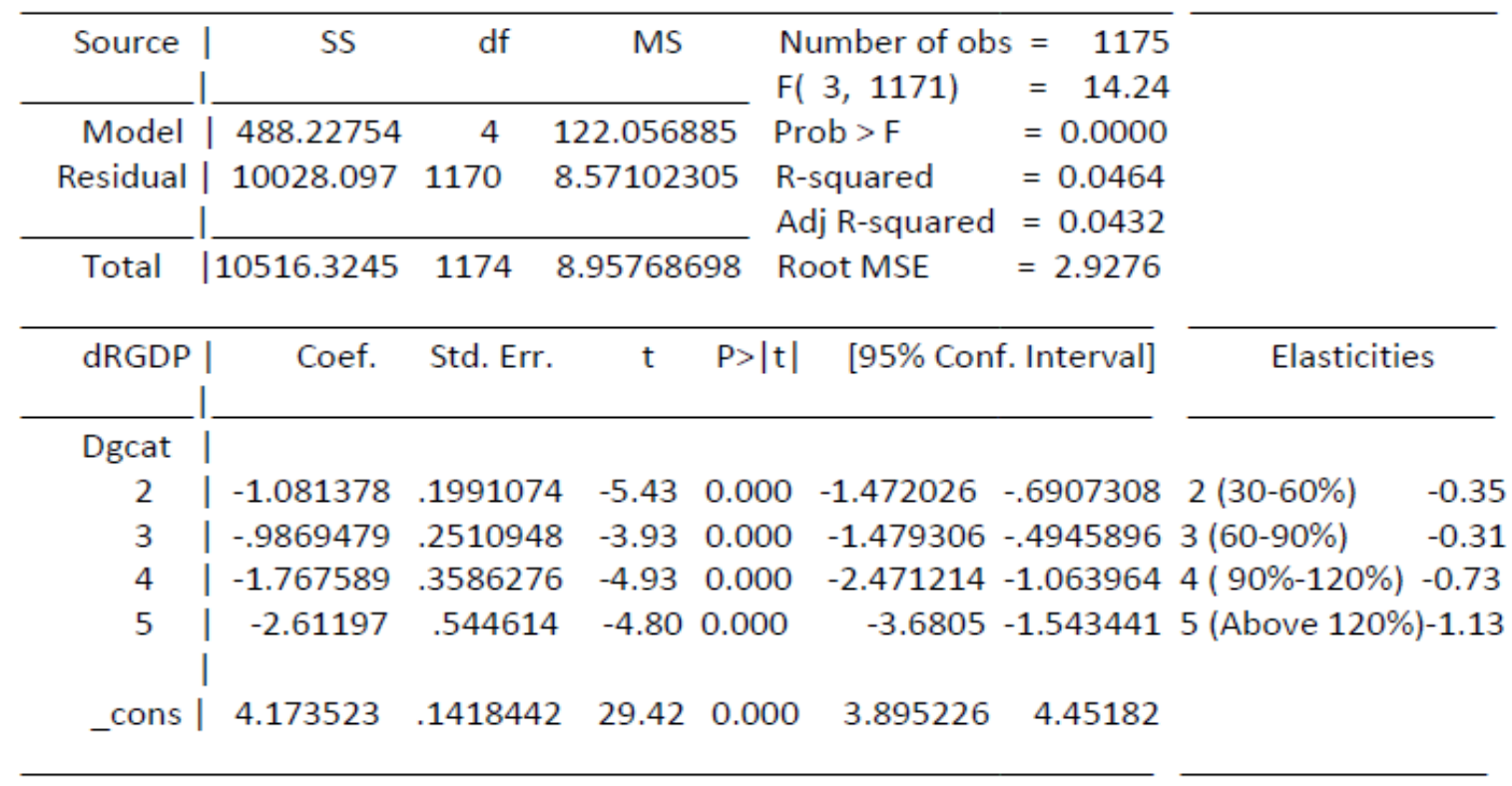

Source: Author's calculation using Reinhart and Rogoff's dataset made public by Herndon et al. (2013).

According to the public debt-to-GDP ratio elasticity of the real GDP growth rate, an increase of $1 \%$ in public debt/GDP category above 90\%, the real GDP growth rate would decrease by $0.93 \%$. Weconclude that public debt/GDP ratio above $90 \%$ does not have a strong negative effect on the economic growth of advanced economies (Table 3).

Model results public debt/GDP category above 120 also show that there exists an inverse relationship between public debt/GDP categories and the real GDP growth rate (Table 4). These relationships for all categories are significant as well.

The estimated equation of this model is written below:

$\mathrm{dRGDP}_{\mathrm{t}}=4.173523-1.081378$ Dgcat $_{\mathrm{t}}-0.9869479$ Dgcat $_{\mathrm{t}}-1.767589$ Dgcat $_{\mathrm{t}}-2.61197$ Dgcat $_{\mathrm{t}}(3)$ (0.1418442) (0.1991074) (0.2510948) (0.3586276) (0.544614)

The estimated values are the average GDP growth rate differences for each category with standard error in parentheses. The annual observations were grouped into categories, according to the higher debt/GDP categories relative to the 0-30 percent public debt/GDP category as follows: the 30-60 percent public debt/GDP category (Dgcat2); 60 to 90 percent (Dgcat3); 90 to 120 percent (Dgcat4); and, above 120 percent (Dgcat5) which is the highest category. The GDP growth rate in the category of public debt/GDP above 120 percent is much lower than the real GDP growth rate in the 30-60 percent and 60-90 percent public debt/GDP categories. This relationship is supported by a research work (Herndon et al., 2013). According to the public debt-to-GDP ratio elasticity of the real GDP growth rate, an increase of $1 \%$ in public debt/GDP category above $120 \%$, the real GDP growth rate would decrease by $1.13 \%$. Weconclude that the public debt/GDP category above $120 \%$ is negatively affecting the real GDP growth rate of advanced countries (Table 4).

Model results also confirm that differences in the average GDP growth rate in the categories 30-60 percent, 60-90 percent, and 90-120 percent cannot be statistically distinguished. An F-test on the hypothesis that, in the 30-60 category, the 60-90 difference, and the 90-120 differences are both zero,cannot be rejected ( $\mathrm{p}$-value $=0.11$ ). These results show that there is a non-linearity in the relationship betweenthe real GDP growth rate and public debt between public debt levels of 0 to 30 percent of GDP and also indicate that the average GDP growth rate tails off somewhat whenthe public 
debt/GDP ratio increases towards 120 percent, but there is no sharp turning point (Herndon et al., 2013). The non-linearity in the relationship between public debt levels and the realGDP growth rate is not around a public debt/GDP ratio of 90 percent where Reinhart and Rogoff have identified it. The non-linearity is not in the domain of public debt/GDP values that is currently the focus of policy debate.

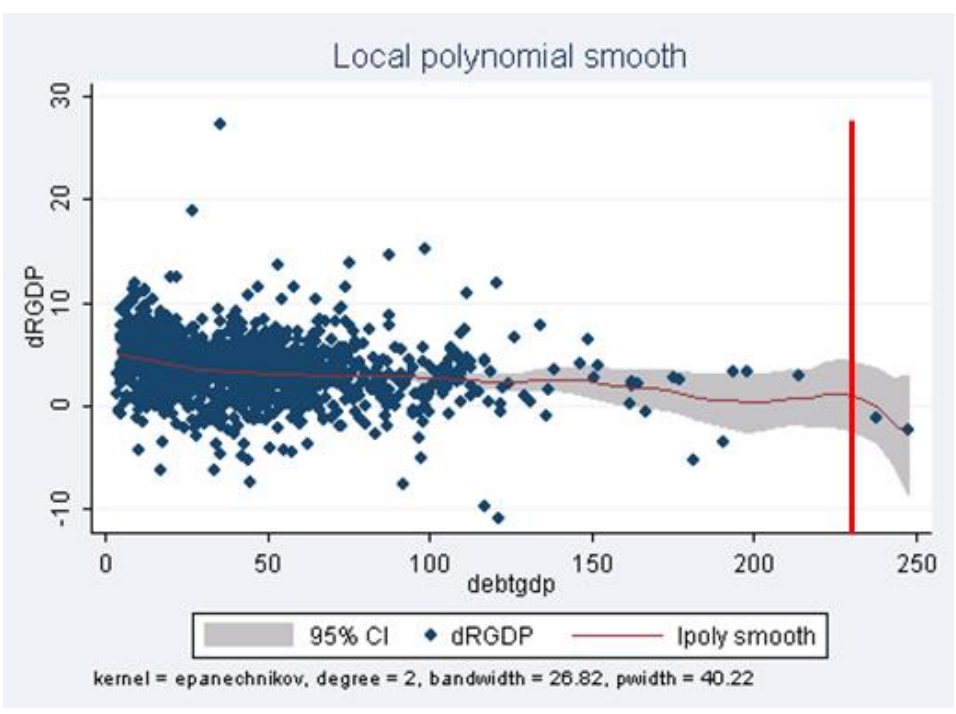

Figure2. Real GDP Growth rate versus public debt/GDP ratio, country years

Source: Author's calculation using Reinhart and Rogoff's dataset made public by Herndon et al. (2013).

A local polynomial smoothed function is estimated using STATA program (Figure 2). The shaded region indicates the 95 percent confidence interval for mean real GDP growth rate. From this graph, we conclude that public debt/GDP ratio above $220 \%$ might be a sharp turning point that can decrease the real GDP growth rate strongly in advanced countries.

\section{CONCLUSION}

Reinhart and Rogoff's research characterized the relationship between public debt and the real GDP growth rate for a range of countries and concluded that countries facing public debt to GDP ratios above 90 percent would experience a major decline in the real GDP growth rate. This research work finds that public debt/GDP ratio would strongly decrease the real GDP growth rate in advanced countries when public debt/GDP ratio might go above 220\%. However, their research work has contributed to ensured that the "traditional debt management issues should be at the forefront of public policy concerns" (Reinhart and Rogoff 2010b, p. 578). Their findings have served as an intellectual bulwark in support of austerity politics (Herndon et al., 2013). Although they have found different results, our model results lead us to reassess the austerity agenda and suggest that the governments should devise new strategies for public debt management in advanced economies, taking into account their economic and financial performance.

Finally, further research needs to be carried out on more complex models. A particular focus on the negative nonlinear relationship between the public debt-to-GDP ratio and the real GDP growth rate appears to be desirable.

\section{REFERENCES}

Atique, R. and K. Malik (2012)," Impact of domestic and external debt on the economic growth of Pakistan", World Applied Sciences Journal 20(1): 120-129.

Baum, A., C. Checherita-Westphal and P. Rother (2012), "Debt and growth: new evidence for the euro area", ECB mimeo.

Brown, R., J. Durbin, and J. Evans, (1975), Techniques for Testing the Constancy of Regression Relationships over Time. JRSS(B) 37:2, 149-163.

Checherita, C. and P. Rother (2010), "The Impact of High and Growing Government Debt on Economic Growth: An Empirical Investigation for the Euro Area," Working Paper Series, No 1237 (August), European Central Bank. 
Caner, M., T. Grennes and F. Koehler-Geib (2010), "Finding the tipping point - when sovereign debt turns bad", World Bank Policy Research Working Paper No. 5391.

Cecchetti, S., M. Mohanty and F. Zampolli (2011), "The real effects of debt", BIS Working Papers No. 352.

Égert, B. (2012), "Public debt, economic growth and nonlinear effects: myth or reality?" OECD Economics Department Working Paper No. 993.

Égert, B. (2015), "The 90\% Public Debt Threshold: The Rise and Fall of a Stylized Fact. OECD Economics Department Working Paper No. 1055.

Elmeskov, J. and D. Sutherland (2012), "Post-Crisis Debt Overhang: Growth and Implications across Countries", OECD Economics Department mimeo, http://www.oecd.org/dataoecd/7/2/ 49541000.pdf

Herndon, T., M. Ash and R. Pollin (2013), "Does high public debt consistently stifle economic growth? A critique of Reinhart and Rogoff", University of Massachusetts Amherst, Political Economy Research Institute Working Paper No. 322.

Johasen, S. and K. Juselius, (1990), "Maximum Likelihood Estimation and Inference on Cointegration- with Applications to the Demand for Money," Oxford Bulletin of Economics and Statistics, Vol. 52, No. 2, pp. 169-210.

Kleiber, C. and J. Acheim (2008). Applied Econometrics with R. Springer-Verlag, New York, USA.

Kumar, M.S. and J. Woo (2010), "Public debt and growth", IMF Working Paper, No. 10/174.

Minea, A. and A. Parent (2012), "Is high public debt always harmful to economic growth? Reinhart and Rogoff and some complex nonlinearities", CERDI working papers No. 2012-18.

$\mathrm{Ng}$, S. and P. Perron, (2001), Lag length selection and the construction of unit root tests with good size and power. Econometrical, Vol. 69, No. 6,November 1519-1554.

Padoan, P.C., U. Sila and P. van den Noord (2012), "Avoiding debt traps: financial backstops and structural reforms", OECD Economics Department Working Paper No. 976.

Panizza, U. and A. Presbitero (2012), "Public debt and economic growth: is there a causal effect? MoFIR Working Paper No. 65.

Rahman, N. (2012), “The relationship between budget deficit and economic growth from Malaysia's perspective: An ARDL approach. International Conference on Economics, Business Innovation IPEDR vol. 38: 54-58.

Reinhart, C.M. and K.S. Rogoff (2010 a), "Growth in a time of debt", NBER Working Paper No. 15639.

Reinhart, C.M. and K.S. Rogoff (2010 b), "Growth in a time of debt", American Economic Review, 100(2), 573-78.

Reinhart, C.M. and K.S. Rogoff (2011), "From financial crash to debt crisis", American Economic Review, 101(5), 1676-1706.

Reinhart, C.M. and K.S. Rogoff (2012), "Public debt overhangs: advanced-economy episodes since 1800", Journal of Economic Perspectives, 26 (3), 69-86.

\section{AUTHOR's BIOGRAPHY}

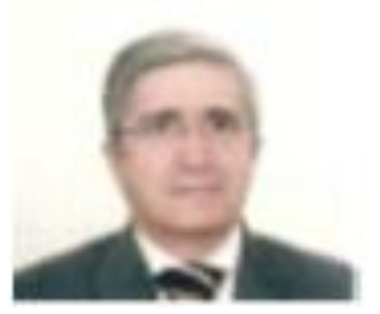

Amílcar Serrão, is Associate Professor at Evora University (Management Department), Evora (Portugal) where he has taught Operations Research, Decisions Models and Research Methodology for more twenty years. He is a PhD from Purdue University (West Lafayette, Indiana, USA, 1988). His works are essentially related to Mathematical Programming, Metaheuristics, Risk, Uncertainty and Ambiguity and Applied Agricultural Financial and Economics Studies. 